AFRICAN

\title{
Forum*: African agency in the context of China-Africa relations
}

\author{
by Lucy Corkin** \\ Rand Merchant Bank - Westport \\ Sandton, South Africa
}

\begin{abstract}
This short extract briefly draws together some of the research conclusions of my book Uncovering African Agency: Angola's Management of China's Credit Lines (Ashgate, 2014). After first providing an overarching context in terms of the importance of rhetoric as a lens through which China-Africa relations are viewed and interpreted, the extract touches on China's approach to foreign relations with African countries and how this has specifically played out in terms of relations between China and Angola. Some key aspects of the Angola's manifestation of "agency" within the parameters of this important diplomatic relationship are outlined.
\end{abstract}

*Forum contributions are discursive and topical articles written by authors to encourage debate or share new information and ideas. Forum articles do not form part of the peer-reviewed section of the AEAA but contribute by extending the academic discussion beyond the limits of a review process.

**Lucy Corkin is currently working with RMB Westport, a real estate equity investment joint-venture, focusing on property developments in sub-Saharan Africa. 


\section{Introduction}

It is clear that rhetoric has shaped our views on China's relations with Africa. This is particularly evident when set in the global context of China attempting to balance its own foreign policy aspirations with Western fears that China's rise is irrevocably disrupting the international architecture. China has good reason to cultivate and maintain allies in developing countries, especially in the face of such suspicion from the industrialised nations. Consequently, Beijing has attempted to alleviate such tensions by projecting itself as a "responsible stakeholder" as conceptualised by the West, particularly with regards to development assistance, while developing "winwin" partnerships in solidarity with the global South.

The tension inherent in a dual role as both a provider of developmental assistance and an "equal partner" with developing countries is not viewed by the Chinese respondents interviewed as a contradiction. Indeed it was striking how many Chinese businessmen described the Chinese role in Angola couched in developmental rhetoric (Manager of private Chinese importing business, 2010), (Chief executive officer of a Chinese import-export company, 2010), (Secretary of the general Party branch, and administrative deputy general manager Beijing Construction Engineering Group, 2010). Generally this was emphasised more by representatives of state-owned enterprises (SOEs), but not exclusively. While the commercial opportunities in Angola were recognised, many insisted they were there to raise the standards of living of the Angolan people and help Angola rebuild itself. One respondent even said:

"Coming to Angola has many benefits, but we have also come across many difficulties: the government is very corrupt, the police give a lot of hassles, there are low levels of work ethic and the roads are not good. The living conditions here are very low, but this is a developing country, in order to serve others we must 'eat bitterness'." (Chief executive officer of a Chinese import-export company, 2010)

The broader Chinese foreign policy rhetoric touts China's engagement with Angola as a successful form of South-South co-operation, and a concrete example of China's relationship with African countries bringing tangible development-oriented results to 


\section{AFRICAN \\ EAST-ASIAN \\ AFFAIRS

a country previously ravaged by a Cold War-fuelled civil conflict and subsequently ignored by the international community. China's growth trajectory is not conveyed as a model ${ }^{1}$ in the sense of providing a blueprint for development, quite the contrary. Beijing offers an alternative to engaging solely with Western countries, and advocates formulating a development path according to a country's own specific context (Obiorah 2008:4).

However, it is clear that equality between China and Africa, difficult enough to substantiate in public rhetoric is not always upheld in personal views. In an illuminating metaphor, a senior official from China Exim Bank, in describing the triangular relationship between China, Africa and Western countries drew a parallel with a child giving a toy that he was tired of to his younger brother:

"After you have given it to your younger brother, it is not your right to tell the younger brother how to play with it”. (China Exim Bank, 2010)

Without reading too deeply into the metaphor, it gives a piercing insight into the way China's relations with Africa are viewed and how passivity is attributed to Africa as a continent by this respondent, despite formal rhetoric of "equal partnership". At the very least China's rhetoric about its role in Africa smacks of noblesse oblige, implying a superior attitude to African countries. Furthermore, China's engagement with African countries is predicated on the need to alleviate its own pressing domestic problems; energy security, securing new export markets and poverty alleviation are far more important drivers of China's foreign policy than South-South solidarity (Cargill, 2010:37).

From a more institutional standpoint, as regards Chinese foreign policy, Li Ruogu, President of China Exim Bank has repeatedly emphasised what he sees as the unrequited success of Chinese firms in Africa, both commercially and as having produced results where Western assistance agents have failed. He sees China Exim bank for example as much more efficient than the Bretton Woods Institutions (BWI), particularly in the case of African countries.

Increased Chinese engagement on the African continent, while sparking reactions 
from the international community, has further led to confrontations regarding civil society within the continent and foreign non-state actors. Many international business groups have accused Chinese companies of low labour and environmental standards in their protests against market entry of Chinese companies. These allegations are often dismissed by the African host governments as "sour grapes". Furthermore, numerous examples of substandard environmental practices by Western companies have seriously diminished the credibility of Western-supported lobby groups for important issues of this nature, regardless of their saliency. Many Chinese commentators are dismissive of so-called Western standards, arguing that they are inappropriate for developing countries:

"You need one or two generations to sacrifice; don't believe the human rights advocates, they are simply put in the wrong time. They are forcing these things which are results of growth, not pre-conditions". (Ruogu, 2010)

This has led commentators such as Richardson (2010) to suggest that China's engagement with Africa:

“... has gone beyond simply a relationship based on trade to a boom in investment that is challenging the classic development paradigms established by Western IFIs such as the IMF and World Bank".

Circumstances differ in this regard from country to country in Africa. In the case of Angola, such claims are overstated. IMF's continued engagement with Angola has been encouraged by Luanda, not least to balance China's influence.

China's foreign policy towards Africa is far from the "grand strategy" concept espoused by Pehnelt and Abel (2007:9). Instead, it is developed incrementally, largely on a trial and error basis and often as a dialogue between principles and agents, or in other words, the various government bureaucracies and state-owned enterprises themselves (Bo, 2010:81). Although Chinese foreign policy overtures to African countries have increased, this must be taken in the context of a more global outreach generally. As Cargill (2010:32) notes:

"There is huge interest in China's African involvement, probably 


\section{AFRICAN \\ EAST-ASIAN \\ AFFAIRS

disproportionately large outside China compared to within it".

Nevertheless, Chinese diplomatic and commercial activity on the continent has increased dramatically from a very low base; despite Africa not being a foreign policy priority relative to other concerns.

An important reason for this, naturally, is China's need for natural resources, particularly petroleum ${ }^{2}$, in which Angola, in terms of securing a long-term supply, has been instrumental. However, new foreign markets are just as important as a release valve for the excess domestic capacity present in nearly all China's productive sectors and Africa is a necessary terrain, to practice "going out" (Western construction equipment importer, 2010).

Africa is thus an important stepping stone in Chinese companies' internationalisation, providing crucial lessons in a less challenging environment than would be provided by other markets.

When put in historical context, it appears that China and Angola's hasty partnership dating from 2004 was a strategic action to address both states' pressing needs at the time. China was experiencing a crippling energy crisis; this period also coincided with the "going global" policy having been officially endorsed by the top Chinese leadership ${ }^{3}$. The Angolan government's oil wealth, which was experiencing financing difficulties just at that time, may have seemed to present a perfect solution. From the perspective of Beijing, several years on the question has been raised as to whether such relations are sustainable as they currently stand (Chinese think tank, 2009). Far from serving as a kind of "model" for other resource rich countries' relations with China, it has been suggested that the strategic partnership forged between Luanda and Beijing was done so at an opportune moment of equal need, for financing and oil resources respectively (Chinese research institute, 2009). This speaks to Angola seizing a "window of time" (Habeeb 1988:34) which presented a unique opportunity.

Furthermore, the Chinese Ministry of Foreign Affairs in view of previous involvement in Angola's history, may have felt it politically expedient to conclude a 
deal, overruling any reservations that that Exim Bank may have harboured (Ministry of Foreign Affairs, 2009). The outcome of the arrangement, has, contrary to the expectations of some, not rendered Chinese oil companies greater access to Angola oil blocks, although supply of oil as collateral has been secured. Despite China providing Angola with substantial financing, this has not facilitated Chinese national oil company (NOC) entry into the oil industry. Chinese companies will continue to bid for oil blocks in Angola, but their progress has been slow. As regards the "going global" policy, China Exim Bank has so far had far more success in opening the door for Chinese construction companies into the Angolan market. China Exim Bank has largely accomplished market entry for a number of Chinese private and state-owned construction enterprises with guaranteed project contracts and procurement shipments totalling several billion US dollars. Chinese construction projects under the China Exim Bank credit line are continuing, with US\$ 2.5 billion in projects reportedly having been executed as of June 2008 (the last formal report to date issued by the Angolan Ministry of Finance regarding process on Chinese-funded infrastructure projects) and phase III of the national reconstruction programme underway (GAT, 2008:2).

As of September 2014, in Angola alone, Chinese companies have cumulatively signed more than US\$ 44.3 billion worth of new contracts, having effectively doubled the value of their project pipeline in five years, when it sat at US\$ 22.6 million in 2009 (MOFCOM, 2014). Consequently, engagement in Angola could be considered a remarkable success as regards the China Exim Banks' mandate to promote Chinese goods and services. Larger state-owned Chinese companies have entered Angola largely on the back of the China Exim Bank credit line, as these state financing structures mitigated the risk that would otherwise have prevented these Chinese firms from entering the little known Angolan market.

Significantly, the oil repayments provide China with secure long-term supply of oil. Angolan exports to China have increased considerably since the China Exim Bank credit line agreement. This seems to point to the fact that the oil is indeed shipped to China, rather than resold on the international market. That the oil must be sold directly to the Chinese state (rather than to a Chinese NOC) is particularly important 


\section{AFRICAN \\ EAST-ASIAN \\ AFFAIRS

for China to build up its strategic reserves. As Bo (2010:93) notes, Chinese NOC's oil equity is often not sent back to China, but sold on the international market at a higher price than can be achieved in China, where the price of oil is controlled. The arrangement between China and Angola thus bypasses the Chinese NOC, alleviating this strategic concern.

A key conclusion from this research is that while the Angolan government was remarkably successful in the negotiation of key terms of financing from China, the implementation of the projects, themselves has been less so. While there are arguably benefits from the physical infrastructure provided as a result of the Chinese contracts, the monitoring of the project execution is questionable. Furthermore, Chinese companies' interaction with Angolans on a commercial level is very weak, limiting opportunities for broader economic stimulation through the reconstruction process itself. This is due to a number of factors; the nature of the Chinese government loans which are specifically a mechanism to ensure that a large proportion of the procurement comes from China (thus reducing China's trade deficit with Angola) and attempted risk mitigation due to Chinese companies' lack of local market knowledge.

In many cases the Chinese companies' competitive advantage lies in their ability to deliver projects faster and cheaper than their competitors, encouraging quick builds to maximum cost and time efficiency. This leaves little room for local content development. Loans from foreign governments, linked to purchasing their national companies' goods and services, especially such as those from China, further reduces the ability of local firms to enter the value chain. A dire lack of training and capacity in a working population that has just emerged from more than three decades of civil war worsens the situation. However, this situation is exacerbated by Angola's weak institutional framework, lack of political will on the Angolan government's part, vested interests preventing local content policy implementation and lack of capacity in the local market.

The Angolan political elite has on the other hand leveraged its growing relationship with China on several levels: the international, the national and the regional. In the 
AFFAIRS

past few years Luanda has acquired access to various lines of credit from a variety of different partners. This points to the Angolan government's successful strategy of diversification of finance sources, compared to its situation immediately following the end of the civil war. The Angolan government, always fiercely protective of its sovereignty, eschewed an IMF structural adjustment package in 2003 for China's less interventionist financing. Considered a "quick-fix" at the time, Luanda continues to be wary of allowing Chinese interests to hold too much sway in the economy. The standby loan agreement drawn up six years later in 2009 between the IMF and Angola points not only to a rapprochement between the African country and the BWI, but is also a determined effort to balance China's perceived influence in the economy. It sends a clear message that Angola is willing to engage with other potential partners. Nevertheless, Chinese financing has been important. It is viewed in some quarters as having acted as a kind of catalyst in attracting financing from other countries (Senior official at Angolan Embassy, 2009).

Regionally, Angola is playing a more active and influential role in forums such at the African Union (AU) and the Southern African Development Community (SADC) (Weimar 2009:4). Despite Sogge's (2009:10) dismissal of Angola's interest in regional bodies such as SADC, he does point to Angola's resurgence of interest in the Nigeria-initiated Gulf of Guinea commission, now headquartered in Luanda. Dos Santos, as the region's longest serving head of state, and leader of the second largest economy after South Africa, is accorded new respect (Mangena, 2011). Furthermore, Angola became the President of OPEC in 2009, two years after becoming its newest member in January 2007.

On the domestic front, in the early years following the end of the civil war, China Exim Bank's loans provided the means to begin national reconstruction. Aside from its practical necessity following the destruction of the civil war, the MPLA government has utilised Chinese financial assistance to kick-start a state-building process through which the government, controlled by the ruling party, could consolidate political and economic power. It also lent credence to the narrative of national reconstruction employed by the government. This was essential from the perspective of political survival and proved successful, given the MPLA's landslide 


\section{AFRICAN \\ EAST-ASIAN \\ AFFAIRS

victory in the legislative elections of 2008. This is what Hodges (2004:169) calls "manufactured legitimacy". The ruling parties' continued control of the credit lines ensured a monopolisation of both the process and the economic rents it implies. Despite a rash of policies and public overtures concerning economic diversification and local participation, the economy's fundamental structural contradictions have not been addressed. Anti-government protests although only in their infancy, are appearing in unprecedented fashion. This underlines the weakness of the Angolan state. The Angolan regime has displayed remarkable political adaptability in navigating its internal and external weaknesses demonstrating significant "behavioural power" (Habeeb 1988:34). However, the political turn of events indicates that the Angolan government will have to further innovate or risk losing its grip on power.

\section{A "strategic partnership"?}

In evaluating the nature of the so-called "strategic partnership" between Angola and China, what emerges is a picture far more complex than previous analyses suggest. Given that Angola has been China's top African trading partner since 2007, there has been a marked lag in the level of China-Angola trade and the corresponding level of China-Angola investment, relative to other resource-rich African countries. In 2009, Angola ranked only $11^{\text {th }}$ in terms of China FDI stock in African countries, with each of the top 10 African destination countries boasting more than double the Chinese investment of Angola's. However, by 2012, with US\$ 392.1 million, Angola ranked $1^{\text {st }}$ in Africa in terms of its Chinese FDI stock according to Chinese Ministry of Commerce official statistics. This seems to infer that five years ago, while Angola was considered an important source of oil, particularly within the West African region, Chinese companies did not regard Angola as a strategic location for investment, beyond acquisitions in the oil industry.

This may be explained by several factors. Firstly, Angola's investment climate is severely lacking. The African country is ranked by the World Bank's 2014 "Doing Business report" as 181 out of 189 (World Bank Group, 2015). According to this report, although ranked $67^{\text {th }}$ for "dealing with construction permits", Angola has a 
AFFAIRS

ranking of 174 for starting a business and 187 for "enforcing a contract". The situation was much the same five years ago. There is little wonder therefore that most Chinese construction companies' entry into Angola's market has been through a tightly managed high-level bi-lateral agreement between the Angolan government and China Exim Bank or CIF. Furthermore, Angola, due to its relative lack of infrastructure and integration into the southern-African region, a legacy of decades of civil war, is not a strategic location of export-oriented manufacture, nor is it a particularly attractive market, relative to other options in Africa, with a modest population of only approximately 22 million, almost 80 per cent of which are considered to be impoverished. Chinese companies benefit predominantly from the Angolan government's oil-fuelled public investment programme facilitated by China Exim Bank. However, as evidenced by the marked jump in investment and with increasing interest from Chinese banking majors Industrial and Commercial Bank of China (ICBC) and China Development Bank (CDB), it appears that this has changed.

Primary interest in Angola for Chinese companies remains the oil sector. The Angolan government, which for decades has directed the Angolan oil industry through its parastatal company Sonangol, has been less open to Chinese investment in the oil industry than originally expected. As we saw, several blocks that various Chinese national oil companies had shown a keen interest in purchasing, were denied them. This may well be for pragmatic reasons; nevertheless, it sends a strong political message to Beijing, and points to shrewd management of the oil industry on the part of the Angolan government, whose management of increasing Chinese interest in the oil sector has been much more deft than Nigeria's (Vines et al, 2009).

African agency should be a key tenet in analysing Africa's international relations. As African actors do have the ability to carve out policy spaces despite the lack of a "level playing field" in international fora. Rather than attributing their current contexts to path dependencies, it must be recognised that the actions of African leadership are at least as important, and as a result, they must accept most of the responsibility for the outcome of such actions (Soares de Oliveira, 2007:124). Angola's political elite has proven adept in managing relations with China, and the Chinese government cannot lay claim to untoward political influence in Angola. 


\section{AFRICAN \\ EAST-ASIAN \\ AFFAIRS

They remain as posited by Campbell and Chaulia (2009:44) "unequal equals". However, "win-win" is largely accorded to political elites in both countries, and business interests that form part of their patronage networks. One key distinction however, is that whereas the Chinese political leadership have arguably succeeded in large-scale poverty reduction ${ }^{4}$ in addition to the success of state institutions and companies, in the Angolan case, at least for now, the accumulation of state power is done at the expense of the Angolan people.

\section{Endnotes}

1. Of interest however is that some countries see China as providing a kind of 'model' for their engagement with Angola. Japan, on whose original foreign aid methods China's own development financing is based, has announced a development assistance package for Angola similar to China's approach, albeit in smaller volumes. (Angop 2011)

2. Bo (2010:65) notes that from $1992-2009,63$ out of 208 investment projects took place in Africa, denoting the region's importance in terms of China's oil -related foreign policy.

3. As discussed by Bo (2010:41) Chinese NOCs had been engaging in overseas operations for more than a decade before the central leadership realised its importance to the economy and promoted it as a general trend for other sectors to follow.

4. According to Kiala (2009:314) China has lifted 400 million people out of poverty since the 1980 's.

\section{Bibliography}

Chief executive officer of a Chinese import-export company. 2010. Personal interview. 10 August, Luanda, Angola. 
AFRICAN

EAST-ASIAN

AFFAIRS

China Exim Bank. 2010. Personal interview. 15 January, Beijing, China.

Chinese research institute. 2009. Personal interview. 9 September, Beijing, China.

Chinese think tank. 2009. Personal interview. 16 October, Beijing, China.

Manager of private Chinese importing business. 2010. Personal interview. 15 July, Luanda, Angola.

Ministry of Foreign Affairs. 2009. Personal interview. 29 October, Beijing, China.

Ruogu, Li. 2010. Presentation at the Tsinghua University School of Public Policy and Management Lecture Series. 11 January, Beijing, China.

Secretary of the general Party branch, and administrative deputy general manager Beijing Construction Engineering Group. 2010. Personal interview. 10 August, Luanda, Angola.

Senior official at Angolan Embassy. 2009. Personal interview. 28 October, Beijing.

Western construction equipment importer. 2010. Personal interview. 15 July, Luanda, Angola.

World Bank Group. 2015. Economy rankings [Online]. Available: http:// www.doingbusiness.org/rankings [2015, February 23]. 